\title{
The Isolation and Identification of Active Compound of Dendrophthoe praelonga (Blume) Miq. Extract Against Breast Cancer Cells (MCF-7)
}
Author
Afiliation
M Irfan Junedi ${ }^{1 *}$, Hendig Winarno ${ }^{1}$, M Hanafi $^{1}$, Nina Artanti ${ }^{2}$
${ }^{1}$ Fakultas Farmasi, Universitas Pancasila, Jakarta, 12640
${ }^{2}$ Kimia, LIPI, Serpong, Banten, 15314,Indonesia.

\section{Keywords}

- Anticancer

- Antioxidant

- Petai plant leaves

Submitted October 12, 2019

Reviewed 7 Juli 2020

Accepted 4 November 2020

*Penulis Koresponding

M Irfan Junedi

email:

irfan.junedi@yahoo.com

\section{ABSTRACT}

Petai mistletoe (Dendrophthoe praelonga (Blume) Miq) is semi-parasitic plant. Parasite plant has been used traditionally in Indonesia to prevent or treat degenerative diseases, such as cancer. The purpose of this study was to indentify anticancer compound of petai mistletoe leaves extract and to examine its antioxidant activity (based on DPPH method) and cytotoxic activity on breast cancer (MCF-7) cell lines in vitro using Alamar blue method. This research aims to isolating, characterize, determine antioxidant activity and cytotoxic activity. Separation was conducting column chromathography and characterize was conducted using TLC, FT-IR, LC-MS and NMR-1 D. From the result obtained, the isolated compound is flavonol quercetine $\left(3,3,7,3^{\prime}, 4^{\prime}\right.$ pethahydroxyflavone) which active antioxidant with $\mathrm{IC}_{50}$ value of $9.4 \mu \mathrm{g} / \mathrm{mL}$ and the value of cytotoxic activity with $\mathrm{IC}_{50} 750.62 \mu \mathrm{g} / \mathrm{mL}$.

\section{INTRODUCTION}

Cancer is a degenerative disease that potentially causes death (Torre et al. 2016). The increased amount of cancer occurrences is triggered by many factors, such as lifestyle, distribution patterns of population, and economic development (Jemal et al. 2011). Breast cancer is a kind of cancer that causes death in $14 \%$ of $30 \%$ of breast cancer sufferers among women (Siegel et al. 2017). One of the efforts in the development of thorough therapies is needed to overcome breast cancer and to reduce the mortality rate of the sufferers (Hanahan et al. 2011).

Chemotherapy techniques in the treatment of cancer have several disadvantages, such as the resistance to particular classes of the cytotoxic drug, side effects, and financial issues in the treatment process (Pearce et al. 2017). Accordingly, it indicates that this kind of cancer therapy has not been efficient, so it is needed for the researchers to develop a chemopreventive agent that can afford both effective and efficient values. Chemopreventive is an agent that potentially inhibits the development of cancer cells, and is able to reduce the growth of abnormal cells, and to reverse the process of carcinogenesis (Ko \& Moon 2015).

A compound, that has the potential as a chemopreventive agent, is able to reduce the risk of cancer by impeding the stages in the initiating preneoplastic lesions by a source of carcinogens. To obtain compounds that have potential as chemopreventive agents are to explore natural materials, especially from some plants (Desai et al, 2008). One of the triggers of cancer can be caused by the free radicals compound that attacks cells of the human body. These free radical compounds are thought to be an initial factor in the onset of cancer including breast cancer (Risky \& Suyatno, 2014). The antioxidant compound is a material that is able to constrain and prevent oxidation of an ingredient or compound that is easily oxidized by radical on an ongoing basis, and is able to reduce oxidative stress (Dai \& Mumper 2010). 
According to the belief in Indonesian people that the parasitic plant (Dendrophthoe pentandra (L.) Miq) is believed to have potential as an anticancer agent with a low toxicity value, and is likely to be an antioxidant (Artani et al. 2012). This is in line with the research conducted by Gamal and Septananda (2013) that parasites that grow on cottonwood plants $(D$. petandra) are able to suppress p53 mutants in HeLa cells in vitro. In addition, based on research conducted by Wicaksono \& Permana (2013) stated that ethanol extracts from mango parasites ( $D$. petandra) can cure the tissue structure in terms of colon cancer.

In this study we reported isolation and identification of active compound from the leaves of the petai parasite (Dendrophthoe praelonga (Blume) Miq), as well as carrying out bioactivity testing such as antioxidant testing by using DPPH method, and cytotoxic testing of breast cancer cells (MCF-7) in vitro by using the alamar blue method. Active compound from extract mistletoe based on analysis of the compound using mass spectroscopy, Infra Red and NMR.

\section{METHODS}

\section{Plant material}

The plant material is mistletoe (Dendrophthoe praelonga (Blume) Miq) grow on petai (Perkia speciosa) tree in Cilegon, Banten, and determination was conducted at Herbarium Bogoriense Bogor

\section{Extraction}

Leaves $D$. praelonga powder $(850$ g) were macerated at room temperature with $n$-hexane for 24 hours (3x2L) and repeated then the residue was macerated with ethylacetate, and ethanol $96 \%$. The filtrates were evaporated under vacuum to obtain a gummy residue.

\section{Antioxidant Activity Test}

Antioxidant analysis was conducted using DPPH (1,1-diphenyl-2 picrylhydrazyl) free scavenging activity (Molyneux, 2004). Various concentration sample diluted in $8 \mathrm{~mL}$ methanol (p.a) mixed with $2 \mathrm{~mL}$ of methanol solution containing DPPH, result in a final concentration of DPPH of $0,1 \mathrm{mM}$ and sample concentration up to $100 \mathrm{\mu g} / \mathrm{mL}$. The mixture was shaken and left for 30 minutes at room temperature. The absorbance was then measured using spectrophotometer at $515 \mathrm{~nm}$.

\section{Isolation and Purification of Ethanol Extract}

The fractionation was conducted using silica gel column chromatograph using increasing solvent polarity (n-hexane, ethyl acetat, and methanol). Activity guided isolation was conducted antioxidant activity using DPPH method (free radical scavenging activity). Fractoions with high antioxidant activity were purified by rinsing methanol a water. Thin Layer Chromatography was conducted throught out the fraction and purification process.

\section{Chromatography Profile of Sample}

Fractions from the ethanol extract were analyzed using thin layer chromatography (TLC). Each sample was eluted using plat $\mathrm{GF}_{254}$ and ODS as stationary phase n-hexane: ethyl acetat (7:3), methanol: ethyl acetat (8:2), and methanol: water (8:2) as mobile phase.

\section{Preparation of cancer cell line}

The cancer cell line used in this research was breast carcinoma (MCF-7). The cells was cultured in RPMI Medium with FBS $10 \%$. The cells was cultured at temperature $37^{\circ}$ with $95 \%$ water content and $5 \% \mathrm{CO}_{2}$ for 3 days until the cells cultures become confluent 60 $70 \%$. After whashing with new medium, it was an incubation again for $24 \mathrm{~h}$. The culturs were then washed with PBS 1-2 times and were suspended using typsinEDTA solution. The cells that have been suspended added with new media.

\section{In vitro anticancer assay}

Toxicity testing of cancer cells using Alamar blue method. The cells line of $100 \mu \mathrm{L}$ of breast cancer cells (MCF-7) added with $10 \mu \mathrm{L}$ of test solution with a concentration variation of $62.5 ; 125 ; 250 ; 500$; and $1000 \mu \mathrm{g} / \mathrm{ml}$. The sample was incubated for 24 hours at $37^{\circ} \mathrm{C}$. The coloring process is performed by adding a blue alamar solution for 4 hours. Color intensity was measured by ELISA (Thermo Fisher Scientific) at a wavelength of $560 \& 590 \mathrm{~nm}$.

\section{Statistical Analysis}

All analytical values shown represent the means of three replicates, were analyzed using one-way ANOVA by SPSS 16.0 (Statistical Package for the Social Sciences) for Windows. Mean separation test between treatments was performed using Duncan's multiple range test. $P$ value $\leq 0.05$ was considered statistically significant. 


\section{RESULTS AND DISCUSSION}

\section{Total yield extracts}

The plant material ( $D$. praelonga) were collected and dried. The plant extracts were collected with different solvents ( $n$-hexane, ethyl acetat and ethanol). The final yield of leaves extracts in different solvents was calculated and listed in Table 1.

\section{Antioxidant Activity Test}

The DPPH scavenging activities of $D$. praelonga leaves crude extracts, fractions, pure compound and the positive control (BHT) are presented in Figure 1. The ethyl acetat and ethanol crude extracts exhibited a potential scavenging effect. However, the $n$-hexane crude extract and Fraction 1 until Fraction 8.

The decreasing scavenging activity of the samples based on the $\mathrm{IC}_{50}$ was in the order; $\mathrm{BHT}>$ pure compound > F-9 until F-18 $>$ ethanol crude extract $>$ ethyl acetat crude extract $>\mathrm{F}-2$ until F-8 $>$ n-hexane crude extract $>$ F-1. Content of polyphenols and flavonoids cause ability the higher antioxidant activity. A compound that acts as an antioxidant is able to inhibit or prevent the oxidation process in a substrate that can be caused by free radicals compounds at small concentrations with a significant reduction (Isnindar et al. 2011). Based on the research conducted by Fauzi et al. (2011), compound that has a potential power of antioxidant can inhibit the growth of breast cancer with $\mathrm{EC}_{50}$ values of $2.4-2.8 \%$. Reported by Fitrilia et al. (2015) water extract of clove mistletoe had DPPH free scavenging activity with $\mathrm{IC}_{50} 11,4 \mu \mathrm{g} \mathrm{mL} \mathrm{m}^{-1}$. Ethanol extract $D$ petandra showed DPPH scavenging activity with value $\mathrm{IC}_{50} 4,74 \mu \mathrm{g} \mathrm{mL} \mathrm{I}^{-1}$ (Widowati, 2013).

Table 1. Extraction yield of $D$. praelonga leaves

\begin{tabular}{lcc}
\hline \multicolumn{1}{c}{ Sample } & Yield (g) & Rendemen (\%) \\
\hline n-Hexane extract & 14.22 & 1.67 \\
Ethyl acetate extract & 16.21 & 1.90 \\
Ethanol 96\% extract & 85.71 & 10.08 \\
\hline
\end{tabular}

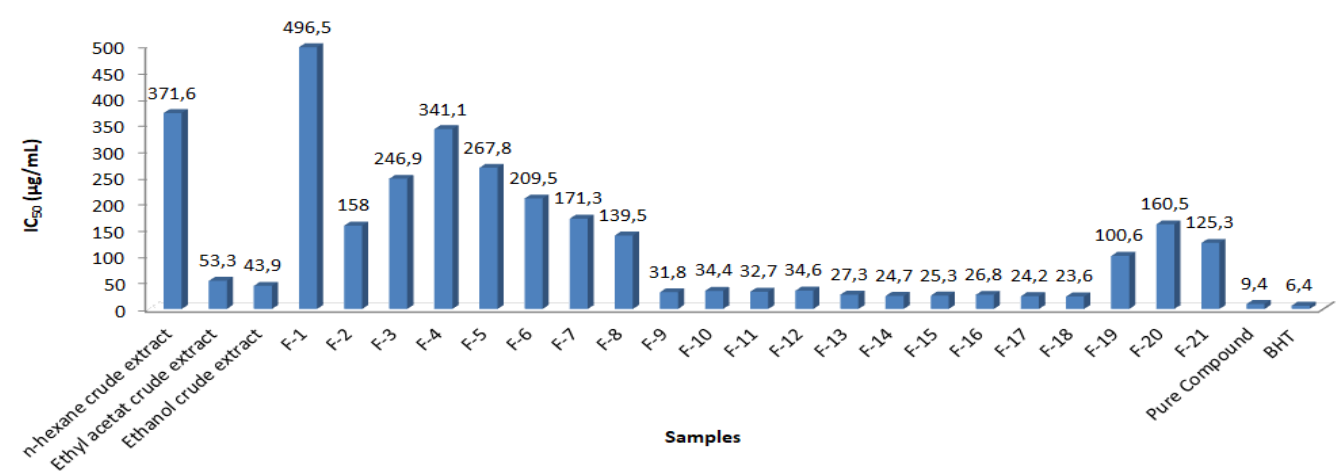

Figure 1. Antioxidant Activity

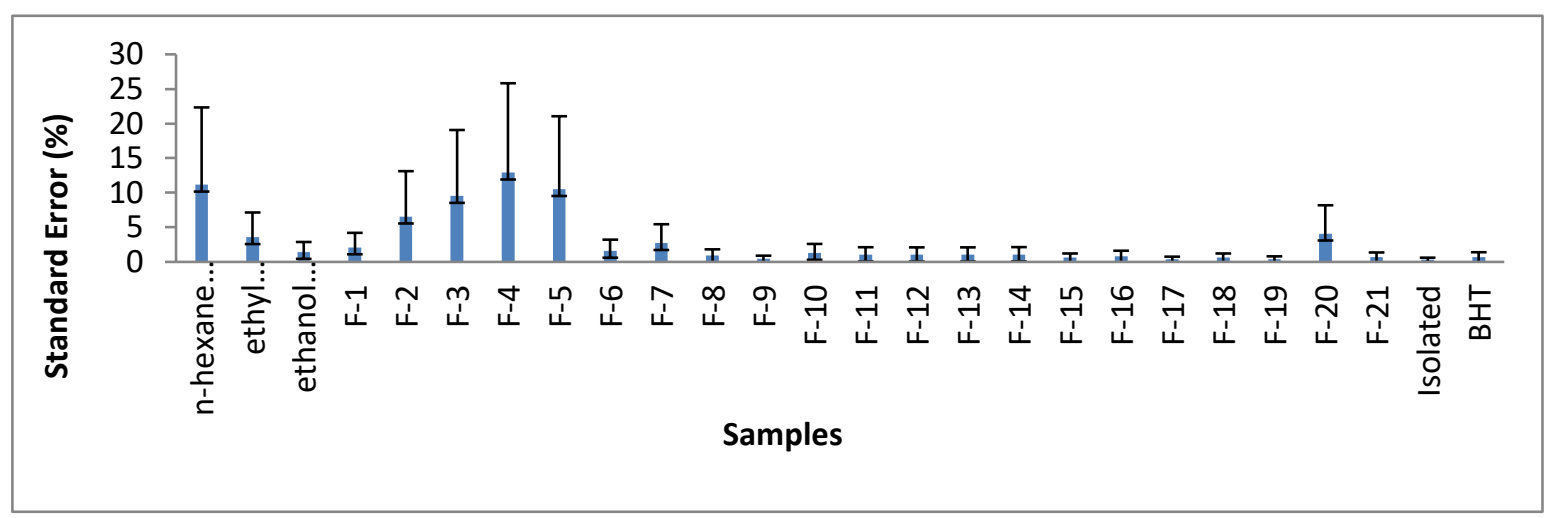

Figure 2. The data is expressed as percentage of antioxidant activity \pm SEM, as compared to the negative control (100\%). Level of significance is $P<0.05$. 


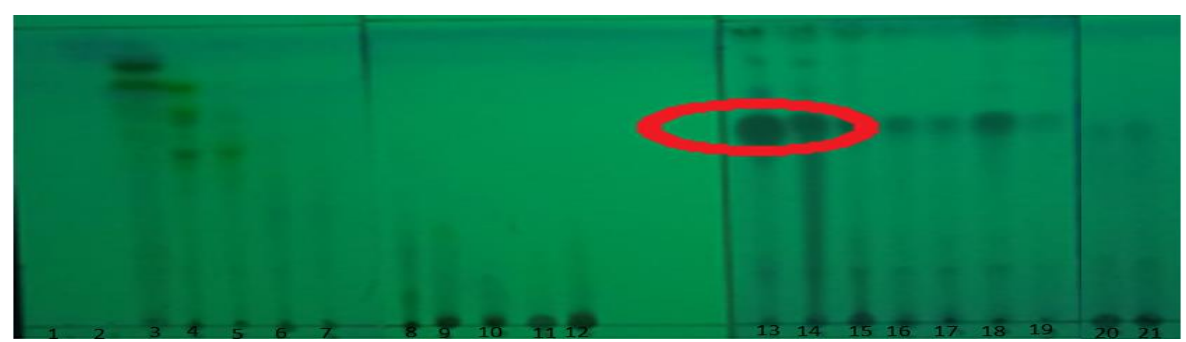

Figure 3. . Result of chromatogram profil TLC of fractions

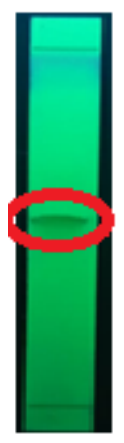

Figure 4. . Result of chromatogram profil TLC of pure compound

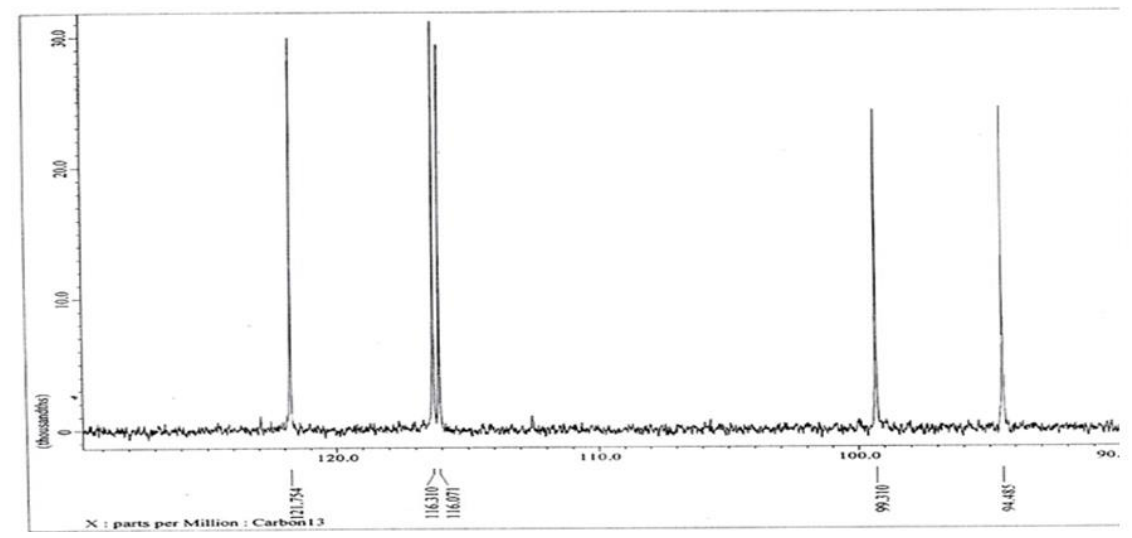

Figure 5. DEPT $135^{\circ}$ spectrum

The antioxidant activity quantified by DPPH in each of the study samples, the lowest value was obtained for $n$-hexane extract and followed fractions (F-1 to F-8 nad $\mathrm{F}-19$ to $\mathrm{F}-21)$ also showed no active as antioxidant $\left(I C_{50}>100 \mu \mathrm{g} \mathrm{m}^{-1}\right)(\mathrm{P}>0,05)$ (Figure 2). The polarity of solvent alters its extraction efect for particular group antioxidant and the influences the scavenging capacity of extract. The ethanol extract and ethyl acetat extract with the highest values followed fractions (F-9 to F-18), isolated compound and positive control (BHT) respectively. Showed the significant radical scavenging activity with $\mathrm{IC}_{50}<50 \mu \mathrm{g} \mathrm{mL} \mathrm{m}^{-1}(\mathrm{P}<0,05)$. DPPH colour was the fading in concentration dependent manner by $D$ praelonga crude extracts, antioxidant activity increased significant $(P<0,05)$ with increasing concentration. The antioxidant activity of $D$. praelonga crude extracts varied the solvents use for extraction using maseration method.

\section{Isolation and Purification of Ethanol Extract}

The fractionation of ethanol extract obtained 21 fractions. It was conducted by using column chromatography techniques in the stationary phase of silica gel, and eluent $n$-hexane, ethylacetate and methanol gradient with a ratio of $10 \%$. The next stage was an TLC analysis of each fraction produced. TLC analysis is shown in Figure 3. 
Table 2. Extraction yield of $D$. praelonga leaves

\begin{tabular}{ccc}
\hline Position C & \multicolumn{2}{c}{$\delta$ (ppm) } \\
\cline { 2 - 3 } $\mathbf{1}$ & $\boldsymbol{\delta} \mathbf{H}(\mathbf{p p m})$ & $\boldsymbol{\delta} \mathbf{C}(\mathbf{p p m})$ \\
$\mathbf{2}$ & & $158,3(\mathrm{~s})$ \\
$\mathbf{3}$ & & $137,3(\mathrm{~s})$ \\
$\mathbf{4}$ & & $177,4(\mathrm{~s})$ \\
$\mathbf{5}$ & & $162,6(\mathrm{~s})$ \\
$\mathbf{6}$ & $6,18(1 \mathrm{H}, \mathrm{d}, \mathrm{J}=2,5)$ & $99,3(\mathrm{~d})$ \\
$\mathbf{7}$ & & $165,6(\mathrm{~s})$ \\
$\mathbf{8}$ & $6,39(1 \mathrm{H}, \mathrm{d}, \mathrm{J}=2,18)$ & $94,4(\mathrm{~d})$ \\
$\mathbf{9}$ & & $148,8(\mathrm{~s})$ \\
$\mathbf{1 0}$ & & $104,6(\mathrm{~s})$ \\
$\mathbf{1}$ & & $121,7(\mathrm{~s})$ \\
$\mathbf{2}^{\prime}$ & & $116,3(\mathrm{~d})$ \\
$\mathbf{3}^{\prime}$ & & $146,3(\mathrm{~s})$ \\
$\mathbf{4}^{\prime}$ & $7,73(1 \mathrm{H}, \mathrm{d}, \mathrm{J}=2,18)$ & $148(\mathrm{~s})$ \\
$\mathbf{5}^{\prime}$ & & $116(\mathrm{~d})$ \\
$\mathbf{6}^{\prime}$ & & $124,2(\mathrm{~d})$ \\
\hline
\end{tabular}

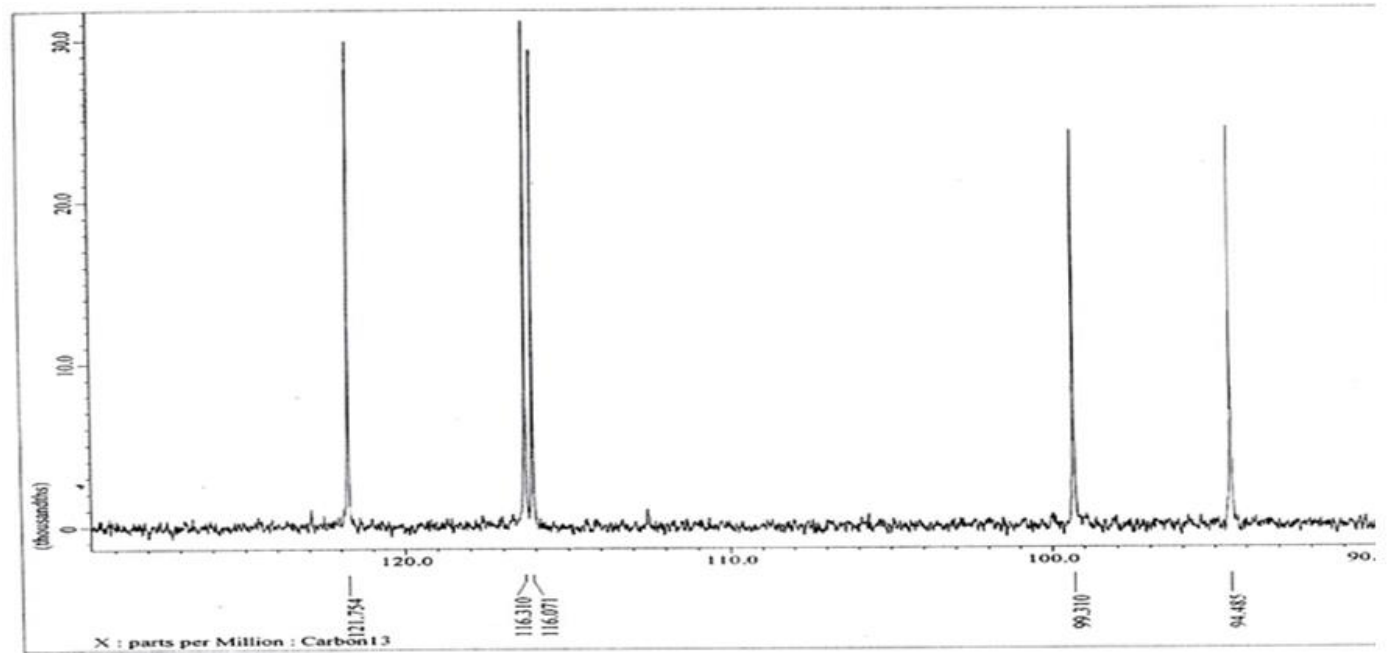

Figure 5. DEPT $135^{\circ}$ spectrum

Based on TLC analysis, fractions 13 and 14 have the same stain pattern and similar ability to reduce the source of radicals, so that the fraction is put together and attained a weight of $300 \mathrm{mg}$. In the next step, the combined fraction was purified by reverse chromatography using stationary phase of ODS and methanol-water eluent isocratically. From the separation technique, we obtained a spot with a pure compound stain pattern shown in Figure 4.

Determination of the chemical structure of pure compounds obtained in the form of amorphous powder in yellow with the formula $\mathrm{C}_{15} \mathrm{H}_{9} \mathrm{O}_{7}$ with a value of $\mathrm{m} / \mathrm{z} 301\left[\mathrm{M}-\mathrm{H}^{+}\right]$. The results of infrared (IR) spectra analysis provide absorption bands at wave numbers $3400 \mathrm{~cm}^{-1}(\mathrm{OH}) ; 1666 \mathrm{~cm}^{-1}$ (C=O); $1520 \mathrm{~cm}^{-1}(\mathrm{C}=\mathrm{C}) ; 1317$ $\mathrm{cm}^{-1}$ (C-O (ether)) and $931 \mathrm{~cm}^{-1}$ (aromatic). After identifying the functional groups and molecular weights of these compound, then an NMR analysis was carried out, which involved protons, carbon, and DEPT $135^{\circ}$. From carbon analysis using the DEPT $135^{\circ}$ technique, it was shown that there are five $\mathrm{sp}^{2}$ metin signals, and nine quaternary $\mathrm{sp}^{2}$ carbon. The DEPT $135^{\circ}$ spectra image is presented in Figure 5. 
<smiles>O=c1c(O)c(-c2ccc(O)c(O)c2)oc2cc(O)cc(O)c12</smiles>

Figure 6. 3,5,7,3', $4^{\prime}$ petahydroxyflavone structure

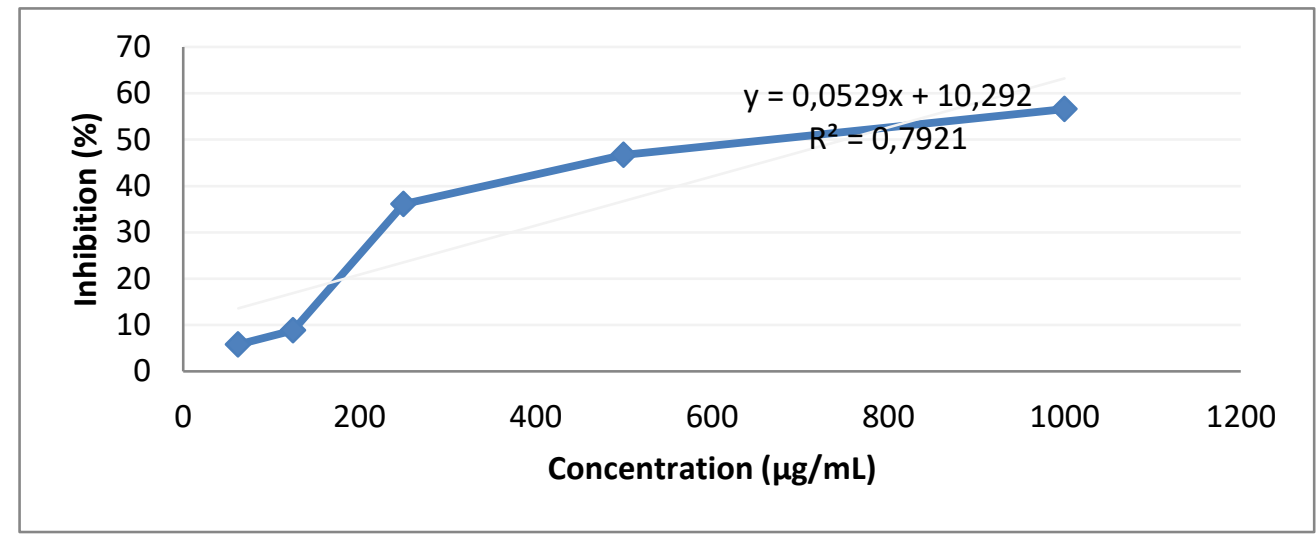

Figure 7. Cytotoxic test of the pure compound

The results of Nuclear Magnetic of Resonance analysis of the proton (NMR) proton and carbon (1D) provide the chemical shift presented in Table 2.

The structure of compound exhibited resonances due to aromatic systems (Figure 6). The aromatic region exhibited $A B X$ system and to a $3^{\prime}$ and 4' substitution dihydroxide of ring $B$ and a typical metacoupled pattern for $\mathrm{H}-6$ and $\mathrm{H}-8$ protons of ring $\mathrm{A}$ and showed the presence of 15 aromatic carbon signals.

\section{Cytotoxic Activity}

Cytotoxic test of the isolated pure compound against MCF- 7 breast cancer cells gave an improvement in terms of inhibition value (\%) along with the increase of sample concentration. Inhibition values (\%) are presented in Figure 7.

According to the chart above, the regression equation is obtained, $y=10,292+0,0529 x$, with an $I C_{50}$ value of $750.62 \mu \mathrm{g} / \mathrm{mL}$. Based on research conducted by Zainudin \& Sul'ain (2015), the ethylacetate extract of $D$. petandra has cytotoxic behaviors against breast cancer cells (MCF-7) with $\mathrm{IC}_{50}$ values of $14 \mu \mathrm{g} / \mathrm{mL}$. Flavonoid bioactive compounds have potential as a source of antioxidants that have a correlation in the process of inhibiting the growth of cancer cells. The bioactive component of flavonoids has anti- carcinogenic properties with its ability to modulate the main target in the cell cycle path. It also has the ability to trigger the process of apoptosis, can inhibit the stages of tumor cell invasion and metastasis, and influence the signaling transduction process (Sandhar et al. 2011).

Based on the data of this research, $\mathrm{IC}_{50}$ towards the relatively pure compounds is not toxic. The low cytotoxic power of pure compound against breast cancer cells (MCF-7) is thought to be the nature of resistance from cells to several compounds that act as anticancer agents. The triggering factors that can cause resistance are influenced by several resistant genes such as multidrug resistance protein (MDR1), multidrug resistance associated protein (MRPs), gluthatione-Stransferase (GST), dihydropyrimidine dehydrogenase (DPD) and galectin (Fulda et al. 2010).

\section{CONCLUSION}

Based on analysis using LC-MS, IR and NMR, it was concluded that the isolated compound from petai mistletoe ( $D$. praelonga) is a flavonol, quercetine $\left(3,5,7,3^{\prime}, 4^{\prime}\right.$ petahydroxyflavone), which has the potential as an antioxidant compound with inhibition values of $9.4 \mu \mathrm{g} / \mathrm{mL}$, and cytotoxic values of breast cancer cells (MCF- 7) of $750.62 \mu \mathrm{g} / \mathrm{mL}$. 


\section{ACKNOWLEDGMENTS}

Thanks to Dr. Hendig Winarno, M.Sc for supporting and discussing this research. Also Prof. (ris). Dr. M. Hanafi, M.Sc for sharing in discussions, and Prof. (ris). Dr. Nina Artanti, M.Sc who has helped the researcher in the steps of cytotoxic testing and physicochemical analysis.

\section{REFERENCES}

Artanti N, Firmansyah T, Darmawan A.2012, Bioactivities evaluation of Indonesian mistletoes (Dendrophthoe pentandra (L.) Miq.) leaves extracts. JAPS. 2(1): 24-27.

Dai J, Mumper RJ. 2010. Plant Phenolics: Extraction, Analysis and Their Antioxidant and Anticancer Properties. Molecules. 15(10): 7313-52.

Desai AG, Qazi GN, Ganju RK, El-Tamer M, Singh J, Saxena AK, et al. 2008. Medicinal plants and cancer chemoprevention. Curr Drug Metab. 9(7): 581-591.

Fauzi AN, Nur Azmi MN, Yaacob NS. 2011. Tualang honey induces apoptosis and disrupts the mitochondrial membrane potential of human breast and cervical cancer cell lines. Food and Chemical Toxicology. 49(4): 871-78

Fulda S, Galuzzi L, Kroemer G. 2010. Targeting mitochondria for cancer therapy. Nature Review. 9(1): 447-461

Gamal, Septananda E. 2013. Potential analysis of cottonwood parasite (Dendropthoe pentandra) stem extract in decreasing of mutant P53 protein expression on cervical cancer cell (HeLa Cells) in vitro. JIMKI. 1(2): 11-15.

Hanahan D, Weinberg RA. 2011. Hallmarks of cancer: the next generation. Cell. 144(5): 646-74.

Isnindar, Wahyuono, S., \& Setyowati, E. P. 2011.Isolasi dan identifikasi senyawa antioksidan daun kesemek (diospyros kaki Thunb.) dengan metode DPPH (2,2Difenil-1 Pikrilhidrazil). Majalah Obat Tradisional. 16(3): 157-164.

Jemal A, Bray F, Center MM, Ferlay J, Ward E, Forman D. 2011. Global cancer statistics. CA Cancer J Clin. 61(2): 69-90.

Ko EY, Moon A. 2015. Natural products for chemoprevention of breast cancer. J Cancer Prev. 20(4): 223-231.
Molyneux, P. 2004. The use of stable free radikal diphenylpicrilhidrazyl (DPPH) for estimating antioxidant activity. Journal Science of Technology. 26(2): 211-9.

N.A.S.N Zainudin and M.D. Sul'ain. 2015. Antiproliferative effect of Dhendrophthoe petandra extract toward human breast adenocarcinoma cell (MCF-7). Jurnal Teknologi. 77(2): 35-39.

Pearce A, Haas M, Viney R, Pearson S-A, Haywood P, Brown $C$, et al. 2017. Incidence and severity of selfreported chemotherapy side effects in routine care. PLOS ONE. 12(10) : e0184360.

Risky TA, Suyatno. 2014. Aktivitas Antioksidan dan Antikanker Ekstrak Metanol Tumbuhan Paku Adiantum philippensis L. J UNESA Chem. 3(1): 8994

Sandhar HK, Kumar B, Prasher S, Tiwari P, Salhan M, Sharma P. 2011. A Review of Phytochemistry and Pharmacology of Flavonoid. Inth Pharm Sci. 1(1): 25-41

Siegel RL, Miller KD, Jemal A. 2017. Cancer statistics. $C A$ Cancer J Clin. 67(1): 7-30.

T. Fitrilia, M Bintang, and M Saithri. 2015. Phytochemical Screening and antioxidant activity of clove mistletoe leaf extract (Dendrophthoe petandra (L) Miq). IOSR Journal of Pharmacy. (5) 8 : 13-18

Torre LA, Siegel RL, Ward EM, Jemal A. 2016. Global cancer incidence and mortality rates and trends--an Update. Cancer Epidemiol Prev Biomark. 25(1): 1627.

Wicaksono MH, Permana S. 2013. Potensi fraksi etanol benalu mangga (Dendrophthoe pentandra) sebagai agen anti kanker kolon pada mencit (Mus musculus Balb/c) setelah induksi Dextran Sulvat (DSS) dan Azoxymethane (AOM). Jurnal Biotropika. 1(2): 7579.

W. Widowati, T. Mozef, C Risdian, H. Ratnawati, S. Tjahjani, and F. Sandra. 2011. The Comparison of Antioxidant and proliferation inhibitor properties of Piper betle L, Catharanthus roseus (L) G.Don ,D.petandra L.,Curcuma manga Val.exctract on T47D cancer line.International Research Journal of Biochemistry and Bioinformatics. 1(2) : 22-28 